\title{
Why are bacteria refractory to antimicrobials?*
}

\author{
Deborah Hogan ${ }^{1}$, Roberto Kolter ${ }^{2 * \star}$ \\ 1. Department of Microbiology and Immunology, Dartmouth Medical School, Hanover, NH, USA \\ 2. Department of Microbiology and Molecular Genetics, Harvard Medical School, Boston, MA, USA
}

\begin{abstract}
Resum. La incidència de la resistència als antibiòtics en bacteris patògens està augmentant. Aquesta resistència es pot aconseguir mitjançant tres rutes clares: amb la inactivació del medicament, amb la modificació de la diana (target) i amb la disminució de la concentració del medicament que arriba a la diana. Des de fa temps se sap que els mecanismes de resistència a antibiòtics específics es poden adquirir a través de mutacions en el genoma bacterià o mitjançant l'addició de més gens durant el trasllat horitzontal de gens. Recentment, també s'ha descobert la importància dels diferents estats fisiològics per a la supervivència dels bacteris en presència d'antibiòtics. Ara és aparent que els bacteris tenen complexos mecanismes de resistència intrínsecs que sovint no es detecten en les proves estàndards de sensibilitat que es fan als antibiòtics en els laboratoris clínics. Entre aquests mecanismes intrínsecs, és de suma importància el desenvolupament de la resistència en bacteris que es troben en agregats associats a superfícies o biopel·lícules.
\end{abstract}

Paraules clau: resistència als antibiòtics · transferència gènica horitzontal $\cdot$ biopel-lícules

\begin{abstract}
The incidence of antibiotic resistance in pathogenic bacteria is rising. Antibiotic resistance can be achieved via three distinct routes: inactivation of the drug, modification of the target of action, and decreasing the concentration of drug that can reach the target. It has long been recognized that specific antibiotic resistance mechanisms can be acquired through mutation of the bacterial genome or by the addition of genes through horizontal gene transfer. Recent attention has also brought to light the importance of different physiological states for the survival of bacteria in the presence of antibiotics. It is now apparent that bacteria have complex, intrinsic resistance mechanisms that oftentimes are not detected in the standard antibiotic sensitivity tests performed in clinical laboratories. Paramount among these intrinsic mechanisms is the development of resistance in bacteria found in surface-associated aggregates or biofilms.
\end{abstract}

Keywords: antibiotic resistance - gene horizontal transfer · biofilms

\section{Introduction}

The identification, characterization, and clinical use of smallmolecule natural products revolutionized medicine in the 20th century. Nowhere is this fact more apparent than in the ability to treat bacterial infections with antibiotics. The morbidity and mortality associated with bacterial infections radically decreased with the discovery and application of antibiotics. The marvelous results observed with penicillin, evident in the seminal work of Fleming, Corey, and Chain, led to a massive search for more antibiotics - a search that by the 1960s had yielded most of the structural classes of antibiotics currently in use.

* Based on the lecture given by Roberto Kolter at the Institute for Catalan Studies, Barcelona, on 7 June, 2007. This article is adapted from Hogan D, Kolter R (2002) Why are bacteria refractory to antimicrobials? Curr Opinion Microbiol 5:472-477.

** Author for correspondence: Roberto Kolter, Department of Microbiology and Molecular Genetics, Harvard Medical School, 200 Longwood Avenue, 02115 Boston, MA (USA). Tel. +1-6174321776. Fax+1-6177387664. Email: rkolter@hms.harvard.edu
The effectiveness of the many antibiotics which thus became available contributed in large part to the declaration in 1967, by the United States Surgeon General, that "it was time to close the book on infectious diseases." Unfortunately, by the 1970s this optimistic view had to be replaced by a much more cautious perspective as the remarkable impact that antibiotics had had in modern medicine was being severely dampened by the widespread emergence of antibiotic resistance in pathogenic bacteria.

Today we recognize that antibiotic resistance is a critical problem in medicine. As early as 1945, when penicillin use was just beginning, Fleming expressed perceptive warnings that penicillin-resistant microbes would arise-a fact that was corroborated in the hospital setting just a year later. Yet, it was not until the 1970s that antibiotic resistance was considered a real threat. By then, the fatalities caused by bacteria resistant to many antibiotics made it clear that the problem of resistance was serious and was not going to be easily controlled.

From an ecological perspective, the emergence of antibiotic resistance as a consequence of the widespread use of antibi- 
otics makes perfect sense. Antibiotic therapy, as wonderful as it is, amounts to a "scorched earth policy" to eradicate bacterial infections. The majority of antibiotics in clinical use today exhibit a very broad spectrum of activity, affecting not only the target pathogen but nearly all of the bacteria present in the human body. In the presence of antibiotics, the rare resistant variants are at an enormous selective advantage - their growth is virtually unimpeded in the absence of competitors. In addition, it is now widely recognized that the antibiotic-sensitive non-pathogenic microbes that inhabit the human body are not merely commensal (present there simply to "have a meal" as that word implies) but rather play important beneficial symbiotic roles. By killing, or at least destabilizing, the communities of these beneficial symbionts, human health is compromised, further complicating the effect of having an antibiotic-resistant pathogen present in the body.

Antibiotic-resistant bacterial infections are becoming increasingly common in the clinical setting [1]. Given the decreasing numbers of novel antibiotics in the "drug development pipeline," there is great concern among clinicians over the appearance of multiply-resistant bacterial strains of problematic pathogens such as Mycobacterium tuberculosis and Staphylococcus aureus [2,3]. In this review, we discuss the recent advances in our understanding of the mechanisms that bacteria use to protect themselves from antibiotics and the means by which they acquire these defenses.

\section{Mechanisms for bacterial resistance to antibiotics}

All antibiotic resistance mechanisms fall into three broad categories: (1) direct inactivation of the active molecule; (2) alteration of the organism's sensitivity to the antibiotic by modification of the target of action, and (3) reduction of the concentration of drug that reaches the target without modification of the compound itself (Fig. 1). The amazing diversity of antibiotic resistance mechanisms is illustrated within each of these three categories.

The production of enzymes that degrade antibiotics falls into the first category of antibiotic resistance mechanisms. Since the discovery of $\beta$-lactamases, enzymes that degrade $\beta$-lactam antibiotics, many other antibiotic-modifying enzymes that confer drug resistance have been found.

Decreased sensitivity to antibiotics due to target modification, the second category defined above, encompasses many diverse microbial strategies. In entercocci, for example, changes in the structure of the cell wall can render bacteria resistant to antibiotics such as vancomycin. Strains that have the vanA or vanB genes produce D-Ala- D-Lac peptidoglycan precursors that are 1000-fold less sensitive to vancomycin than the wildtype D-Ala- D-Ala form. Also, a novel plasmid-encoded protein that confers resistance to quinolone antibiotics has been discovered [4,5]. The protein protects DNA gyrase from quinolone inhibition without modifying the drug, but the protective mechanism is not known.

Most of the recent excitement in the field of antibiotic resistance has focused on the third category of drug resist-

\section{Alteration of target}

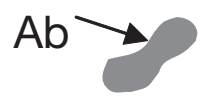

"y
Drug inactivation

\section{Low} permeability
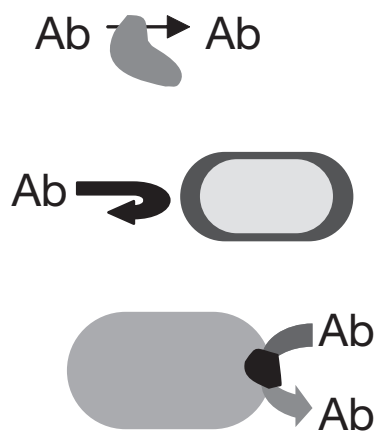

Fig. 1. Mechanisms of resistance to antibiotics (Ab).

ance mechanisms, reduction of the antibiotic concentration. Because the efficacy of antibiotics depends on their ability to reach their target, factors that influence the accumulation of drugs within the cell can be very effective in increasing antibiotic resistance. This remainder of this article focuses on developments in this area of bacterial resistance to antibiotics.

\section{Efflux pumps}

Efflux pumps can affect both intrinsic and acquired resistance to many different antibiotics by using energy to reduce the cytoplasmic drug concentration to subtoxic levels. The analysis of genome sequences has shown that many bacteria appear to have multiple, putative efflux pumps $[6,7,8]$. The activity of these pumps contributes to the high levels of antibiotic resistance exhibited by organisms such as Pseudomonas aeruginosa [9].

Efflux pumps vary in both their specificity and mechanism. Single-drug transporters include ABC transporters and pumps driven by the proton-motive force. Many organisms also possess multidrug transporters that are capable of expelling a wide spectrum of structurally unrelated drugs from prokaryotic cells. Some multidrug resistance pumps, such as the Lmr ATP-dependent $A B C$ transporter from gram-positive bacteria, are homologous to efflux pumps that inhibit the action of chemotherapeutic agents in eukaryotic cells [6]. It has been proposed that these efflux pumps act as "hydrophobic vacuum cleaners" by pumping non-polar compounds from the membrane to the exterior of the cell [10]. Other multidrug exporters, such as QacA from $S$. aureus, use the proton-motive force to drive the removal of cationic and lipophilic antimicrobial compounds [11]. Until recently, all of the known multidrug efflux pumps in gram-negative bacteria belonged to either the RND (resistance-nodulation-divi- 
sion) transporter family or the SMR (small multidrug resistance) transporter family. However, a recently described macrolidespecific efflux pump in Escherichia coli was found to be an ABC transporter [12]. Inducible multidrug efflux pumps are responsible for the intrinsic antibiotic resistance of many organisms and mutation of the regulatory elements that control the production of efflux pumps can lead to an increase in antibiotic resistance. For example, the MexAB-OprM in $P$. aeruginosa is normally positively regulated by the presence of antibiotics [13], yet mutations in its regulator, mexR, lead to the overexpression of MexAB-OprM, conferring increased resistance to $\beta$-lactam antibiotics [14]. The broad-spectrum nature of efflux pumps and their ability to be transferred between microorganisms make them a serious threat to the efficacy of antibiotics in the clinical setting.

\section{Cell permeability}

The permeability of the bacterial cell envelope also greatly influences the ability of antibiotics to enter the cell. For example, the waxy, lipid-rich outer layers of mycobacteria render these organisms more resistant to killing by antimicrobial compounds. Gram-negative bacteria are protected from antibiotics by the negatively charged lipopolysaccharides in their outer membrane, which limit the entry of hydrophobic antibiotics into the cell [15]. While small, hydrophilic molecules can cross the membrane through non-specific porins, larger, more hydrophobic compounds, such as siderophores and vitamins, can only enter the cell through specialized porins. A recent report on a multidrug resistant strain of Enterobacter aerogenes showed that a single change in the sequence of an outer membrane porin can led to the decreased diffusion of $\beta$-lactam antibiotics into the cell, thus increasing resistance to these antibiotics [16].

In contrast to mycobacteria and gram-negative microorganisms, most gram-positive organisms are not well-protected from penetration by antibiotics. The cell wall, a thick peptidoglycan layer, does not impede the movement of molecules less than $50 \mathrm{kDa}$. However, modifications of the cell wall's structure can significantly decrease the permeability of the cell envelope to antibiotics. For instance, the intermediate vancomycin-resistance phenotype in $S$. aureus is due to an increased amount of non-amidated glutamine residues in the peptidoglycan. It has been suggested that the increased resistance in these strains is due to the "affinity trapping" of vancomycin in the thickened cell wall $[17,18]$.

\section{Mechanisms for acquiring novel resistance}

Bacteria acquire resistance through several different routes, including mutation of the bacterial genome and acquisition of new genes through horizontal transfer of plasmids and transposons. Researchers continue to identify new and exciting aspects of both of these acquisition mechanisms, as described below. Recently, researchers have also begun to address how different physiological states of bacteria specifically affect resistance to antibiotics.

\section{Mutation}

Chromosomal mutations can lead to antibiotic resistance in a number of different ways. For example, a recently identified mutation in the 16S rRNA gene of a Helicobacter pylori isolate makes the cells resistant to tetracycline, presumably by alteration of the antibiotic binding site [19]. Alternatively, as described above, mutations in regulators or regulatory regions can contribute to antibiotic resistance by leading to the overproduction of either intrinsic resistance determinants, such as efflux pumps, or the target itself which may overcome total inhibition by the drug.

In recent years, much attention has been given to the idea that, within the host, mutations arise at a frequency that is higher than what is observed in vitro [20]. The presence of diverse variants within a single host was demonstrated in a recent study of $E$. coli strains taken from spatially separated cysts within a single patient receiving long-term antibiotic therapy. The E. coli isolates displayed many different phenotypic properties, including a range of antibiotic resistance levels, even though genetic analyses suggested that these strains were derived from the same founder population [21]. A number of studies have suggested that a "mutator" phenotype is selected for within the host. Isolates of $P$. aeruginosa obtained from the sputum of cystic fibrosis (CF) patients with persistent infections had higher mutation rates than $P$. aeruginosa from non-CF patients [22]. Interestingly, the $P$. aeruginosa strains with higher rates of mutation showed significantly higher levels of resistance to antibiotics. Genotype analysis of strains isolated from the same patient strongly suggests that the mutator phenotypes actually evolve in the host over time. Mutator phenotypes have also been identified in other bacteria. A survey of over 600 E. coli and Shigella isolates collected from different clinical samples found that strains associated with urinary tract infections had higher mutation frequencies than those implicated in septicemia [16]. Although the strains with higher mutation frequencies were not more resistant to clinically relevant antibiotics, the rate at which resistant colonies arose in the presence of high antibiotic concentrations was much higher in mutator strains than in the wild-type. A number of different factors could contribute to an increased mutation rate within the host, including the presence of pockets within an infection that only receive low doses of antibiotics [22,23]. An understanding of the control of mutation rates in the host environment will contribute to the design of antibiotic therapies that limit the selection for antibiotic-resistant bacteria.

\section{Horizontal gene transfer}

Since the discovery of the R factor, in the 1960s, it has been known that mobile genetic elements, such as plasmids and transposons, are important agents for the transfer of antibiotic resistance determinants between bacteria. These factors allow for the rapid, global dissemination of genes that confer antibiotic resistance, especially within hospital settings. Integrons, genetic elements that can encode several different antibiotic 
resistance genes, have also contributed to the problem of antibiotic resistance in bacteria [24]. Indeed, integrons that contain up to eight different antibiotic resistance cassettes have been found in multidrug resistant clinical isolates [25]. Furthermore, superintegrons, which encode many different functions, have been found in Vibrio cholerae [26] and in non-pathogenic environmental Pseudomonas strains [27], emphasizing the importance of integrons in the genetic exchange of elements, such as those that confer antibiotic resistance, among gram-negative bacteria.

\section{Physiology-dependent resistance}

Biofilm resistance to antibiotics. Bacterial biofilms that form on surfaces contain a high density of bacterial cells surrounded by an extracellular matrix. In general, bacteria within biofilms tolerate higher levels of antibiotics than comparable planktonic cells. The difficulties in treating biofilm-related infections on catheters and medical implants are thought to be due, at least in part, to the increased antibiotic resistance of biofilm bacteria. Although biofilms have some properties in common, their structure and composition depend on the component microorganisms and environmental conditions. Thus, in different situations, the level of antibiotic resistance may vary and the factors that give rise to the increased resistance may differ.

Multiple factors likely to contribute to biofilm-associated antibiotic resistance include slow growth rates, decreased diffusion of antibiotics through the biofilm, the accumulation of enzymes that contribute to resistance, or the activation of stress responses in bacteria within the biofilm (reviewed recently in $[28,29])$. Several studies have examined the basis for biofilm antibiotic resistance in more detail. In Klebsiella pneumoniae biofilms, the diffusion of ampicillin and ciprofloxicin was not impeded by the biofilms themselves, but the levels of antibiotics within the biofilm were reduced due to the activity of $\beta$-lactamases. Since $\beta$-lactamase production alone did not account for the resistance of biofilm bacteria to antibiotics, the authors suggested that other, uncharacterized elements are also important for resistance to antibiotics [30]. The factors that confer antibiotics resistance also depend on the drug itself. Multiple factors, including the presence of matrix, slow growth rates, and high cell densities, contribute to the increased resistance of Staphylococcus epidermidis biofilms to glycopeptides, but these factors do not explain the increased resistance of this bacterium to other classes of antibiotics [31].

The increased resistance of biofilm bacteria to antibiotics is due to several different mechanisms. Signals that control gene regulation, such as quorum-sensing compounds, are present in biofilms at levels that might regulate the expression of genes related to antibiotic resistance. Because the presence of efflux pumps is largely responsible for antibiotic resistance in many organisms, it was hypothesized that efflux pumps are more abundant in biofilm cells than in planktonic cells. However, mutational analysis and gene expression studies of genes that encode known drug efflux pumps indicated that this is not necessarily the case $[30,32]$. A comparison of the RNA expression profiles from $P$. aeruginosa planktonic cultures and biofilms identified several candidate genes that may contribute to the antibiotic resistance phenotype of biofilm cells [33]. For example, increased expression of the tolA gene is hypothesized to alter the structure of lipopolysaccharides in the outer membrane, making it more difficult for aminoglycoside antibiotics, such as tobramycin and gentamicin, to enter the cell. In addition, genes that encode porins or electron transport proteins are differentially expressed in biofilms and may also contribute to bacterial antibiotic resistance. When biofilms were challenged with high concentrations of tobramycin, two efflux systems as well as stress response proteins and several hypothetical proteins were induced, but the role of these components in the antibiotic resistance of biofilm bacteria has not yet been tested directly.

Stationary-phase-induced resistance. It has been welldocumented that slow growth rates resulting from nutrient limitation are accompanied by an increased resistance to multiple antibacterial compounds due to low metabolic activities and to decreased cell permeability [34]. Furthermore, slow growth is also correlated with the increased expression of multidrug efflux genes, specifically, acrAB in E. coli, by an RpoS-independent mechanism [35]. A recent paper suggested that $E$. coli stationary-phase cultures produce a diffusible factor that is different from the known quorum-sensing systems that induces resistance to antibiotics in growing $E$. coli cells. The nature of the signal or the response of cells to the signal is not yet known [36]. It has been proposed that in stationary-phase cultures there are subpopulations of antibiotic-resistant "persister cells" that lead to the increased resistance to antibiotics [37] Persister cells are not mutants and do not produce antibioticresistant offspring in the absence of antibiotic. The mechanisms by which persister cells are formed or the factors that contribute to their antibiotic resistance are not yet known.

Phenotypic variation within bacterial populations. Antibiotic resistance is often associated with decreased fitness in the absence of antibiotics [38]. Consequently, bacteria have developed mechanisms to mitigate the growth disadvantage conferred by antibiotic resistance while ensuring their own survival in the presence of antibiotics. Small colony variants (SCV) of $S$. aureus appear in the presence of gentamicin both in vitro and in vivo [39]. Entry into the SCV form is reversible upon growth in antibiotic-free medium. Cycling between the resistant SCV and the antibiotic-sensitive larger colony form can occur multiple times, indicating that SCVs are not formed by mutation but rather through a regulatory mechanism or phase variation. Similarly, a recent paper by Drenkard and Ausubel [40] reported that rough small colony variants (RSCV) frequently arise within $P$. aeruginosa populations at varying frequencies under different conditions. RSCVs have a number of phenotypic differences from the "parental" form, including increased resistance to multiple antibiotics. A gene that influences the frequency with which bacteria switch from the antibiotic-sensitive large colony variant to the resistant RSCV form has been identified, but the mechanism for switching between forms is not yet 
known. Interestingly, RSCVs also have an increased rate of attachment to plastic, perhaps due to a more hydrophobic cell surface, and form larger biofilms than wild-type bacteria. These findings suggest that there is a direct link between biofilm formation and antibiotic resistance. Similarly, it will be interesting to explore the possible connection between the "persister cells" that form in stationary-phase cultures and the variants that arise in response to antibiotics, as both show increased antibiotic resistance. Even though the specific physiological basis for increased antibiotic resistance is not yet known, findings such as these may contribute to the development of therapies targeting pathogenic bacteria in the physiological states that predominate within the host.

\section{Conclusions}

In many cases, several different antibiotic resistance mechanisms act in concert to protect a bacterium from the concentrations of antibiotics that are used in clinical settings [41,42]. Furthermore, some clinical isolates develop high levels of resistance by combining different strategies for protection from exposure to antibiotics [43]. In our search for new antibiotics for therapeutic use, we must consider all of the intrinsic, mutational, and physiological resistance mechanisms present in bacteria.

\section{References}

[1] Pfaller MA, Jones RN, Doern GV, Kugler K (1998) Bacterial pathogens isolated from patients with bloodstream infection: frequencies of occurrence and antimicrobial susceptibility patterns from the SENTRY antimicrobial surveillance program (United States and Canada, 1997). Antimicrob Agents Chemother 42:1762-1770

[2] Jones RN, Low DE, Pfaller MA (1999) Epidemiologic trends in nosocomial and community-acquired infections due to antibiotic-resistant gram-positive bacteria: the role of streptogramins and other newer compounds. Diagn Microbiol Infect Dis 33:101-112

[3] Zumia A, Grange JM (2001) Multidrug-resistant tuberculosis - can the tide be turned? Lancet Infect Dis 1:199-202

[4] Martinez-Martinez L, Pascual A, Jacoby GA (1998) Quinolone resistance from a transferable plasmid. Lancet 351:797-799

[5] Tran JH, Jacoby GA (2002) Mechanism of plasmid-mediated quinolone resistance. Proc Natl Acad Sci USA 99:5638-5642

[6] Blackmore CG, McNaughton PA, van Veen HW (2001) Multidrug transporters in prokaryotic and eukaryotic cells: physiological functions and transport mechanisms. Mol Membr Biol 18:97-103

[7] Hoskins J, Alborn WE Jr, Arnold J, Blaszczak LC, Burgett S, DeHoff BS, Estrem ST, Fritz L, Fu DJ, Fuller W, et al. (2001) Genome of the bacterium Streptococcus pneumoniae strain R6. J Bacteriol 183:5709-5717
[8] Stover CK, Pham XQ, Erwin AL, Mizoguchi SD, Warrener P, Hickey MJ, Brinkman FS, Hufnagle WO, Kowalik DJ, Lagrou M, et al. (2000) Complete genome sequence of Pseudomonas aeruginosa PA01, an opportunistic pathogen. Nature 406:959-964

[9] Levy SB (2002) Active efflux, a common mechanism for biocide and antibiotic resistance. J Appl Microbiol 92 Suppl 1:65S-71S

[10] Sharom FJ, Liu R, Qu Q, Romsicki Y (2001) Exploring the structure and function of the P-glycoprotein multidrug transporter using fluorescence spectroscopic tools Semin Cell Dev Biol 12:257-265

[11] Brown MH, Skurray RA (2001) Staphylococcal multidrug efflux protein QacA. J Mol Microbiol Biotechnol 3:163170

[12] Kobayashi N, Nishino K, Yamaguchi A (2001) Novel macrolide-specific ABC-type efflux transporter in Escherichia coli. J Bacteriol 183:5639-5644

[13] Masuda N, Sakagawa E, Ohya S, Gotoh N, Tsujimoto H, Nishino T (2000) Contribution of the MexX-MexY-oprM efflux system to intrinsic resistance in Pseudomonas aeruginosa. Antimicrob Agents Chemother 44:2242-2246

[14] Pai H, Kim J, Lee JH, Choe KW, Gotoh N (2001) Carbapenem resistance mechanisms in Pseudomonas aeruginosa clinical isolates. Antimicrob Agents Chemother 45:480-484

[15] Denyer SP, Maillard JY (2002) Cellular impermeability and uptake of biocides and antibiotics in Gram-negative bacteria. J Appl Microbiol 92 Suppl 1:35S-45S

[16] De E, Basle A, Jaquinod M, Saint N, Mallea M, Molle G, Pages JM (2001) A new mechanism of antibiotic resistance in Enterobacteriaceae induced by a structural modification of the major porin. Mol Microbiol 41:189-198

[17] Peschel A, Vuong C, Otto M, Gotz F (2000) The D-alanine residues of Staphylococcus aureus teichoic acids alter the susceptibility to vancomycin and the activity of autoIytic enzymes. Antimicrob Agents Chemother 44:28452847

[18] Pfelt, RF, Singh VK, Schmidt, JL, Batten MA, Baranyk CS, Nadakavukaren MJ, Jayaswal RK, Wilkinson BJ (2004) Characterization of passage-selected vancomycin-resistant Staphylococcus aureus strains of diverse parental backgrounds. Antimicrob Agents Chemother 44:294-303

[19] Trieber CA, Taylor DE (2002) Mutations in the $16 \mathrm{~S}$ rRNA genes of Helicobacter pylori mediate resistance to tetracycline. J Bacteriol, 184:2131-2140

[20] Baquero F, Negri MC, Morosini MI, Blázquez J (1998) Antibiotic-selective environments. Clin Infect Dis 27 Suppl 1:S5-11

[21] Low AS, MacKenzie FM, Gould IM, Booth IR (2001) Protected environments allow parallel evolution of a bacterial pathogen in a patient subjected to long-term antibiotic therapy. Mol Microbiol 42:619-630

[22] Oliver A, Canton R, Campo P, Baquero F, Blazquez J (2000) High frequency of hypermutable Pseudomonas aeruginosa in cystic fibrosis lung infection. Science 288:1251-1254 
[23] Gould IM, MacKenzie FM (2002) Antibiotic exposure as a risk factor for emergence of resistance: the influence of concentration. J Appl Microbiol, 92 Suppl 1:78S-84S

[24] Stokes HW, Hall RM (1989) A novel family of potentially mobile DNA elements encoding site-specific gene-integration functions: integrons. Mol Microbiol 3:1669-1683

[25] Naas T, Mikami Y, Imai T, Poirel L, Nordmann P (2001) Characterization of In53, a class 1 plasmid-and composite transposon-located integron of Escherichia coli which carries an unusual array of gene cassettes. J Bacteriol 183:235-249

[26] Rowe-Magnus DA, Guerout AM, Mazel D (2002) Bacterial resistance evolution by recruitment of super-integron gene cassettes. Mol Microbiol 43:1657-1669

[27] Vaisvila R, Morgan RD, Posfai J, Raleigh EA (2001) Discovery and distribution of super-integrons among pseudomonads. Mol Microbiol 42:587-601

[28] Gilbert P, Allison DG, McBain AJ (2992) Biofilms in vitro and in vivo: do singular mechanisms imply cross-resistance? J Appl Microbiol 92 Suppl 1:98S-110S

[29] Mah TF, O'Toole GA (2001) Mechanisms of biofilm resistance to antimicrobial agents. Trends Microbiol 9:34-39

[30] Anderl JN, Franklin MJ, Stewart PS (2000) Role of antibiotic penetration limitation in Klebsiella pneumoniae biofilm resistance to ampicillin and ciprofloxacin. Antimicrob Agents Chemother 44:1818-1824

[31] Konig C, Schwank S, Blaser J (2001) Factors compromising antibiotic activity against biofilms of Staphylococcus epidermidis. Eur J Clin Microbiol Infect Dis 20:20-26

[32] De Kievit T, Parkins M, Gillis R, Srikumar R, Ceri H, Poole K, Iglewski B, Storey D (2001) Multidrug efflux pumps: expression patterns and contribution to antibiotic resistance in Pseudomonas aeruginosa biofilms. Antimicrob Agents Chemother 45:1761-1770

[33] Whiteley M, Bangera MG, Bumgarner RE, Parsek MR, Teitzel GM, Lory S, Greenberg EP (2001) Gene expression in Pseudomonas aeruginosa biofilms. Nature 413:860864

[34] Brown MR, Williams P (1985) The influence of environment on envelope properties affecting survival of bacteria in infections. Annu Rev Microbiol 39:527-556

[35] Rand JD, Danby SG, Greenway DL, England RR (2002) Increased expression of the multidrug efflux genes acr $A B$ occurs during slow growth of Escherichia coli. FEMS Microbiol Lett 207:91-95

[36] Heal RD, Parsons AT (2002) Novel intercellular communication system in Escherichia coli that confers antibiotic resistance between physically separated populations. J Appl Microbiol 92:1116-1122

[37] Spoering AL, Lewis K (2001) Biofilms and planktonic cells of Pseudomonas aeruginosa have similar resistance to killing by antimicrobials. J Bacteriol 183:6746-6751

[38] Andersson DI, Levin BR (1999) The biological cost of antibiotic resistance. Curr Opin Microbiol 2:489-493

[39] Massey RC, Buckling A, Peacock SJ (2001) Phenotypic switching of antibiotic resistance circumvents permanent costs in Staphylococcus aureus. Curr Biol 11:1810-1814

[40] Drenkard E, Ausubel FM (2002) Pseudomonas biofilm formation and antibiotic resistance are linked to phenotypic variation. Nature 416:740-743

[41] Bearden DT, Danziger LH (2001) Mechanism of action of and resistance to quinolones. Pharmacotherapy 21:224S232S

[42] Chopra I, Roberts M (2001) Tetracycline antibiotics: mode of action, applications, molecular biology, and epidemiology of bacterial resistance. Microbiol Mol Biol Rev 65:232-260

[43] Le Thomas I, Couetdic G, Clermont O, Brahimi N, Plesiat $P$, Bingen $E$ (2001) In vivo selection of a target/efflux double mutant of Pseudomonas aeruginosa by ciprofloxacin therapy. J Antimicrob Chemother 48:553-555

\section{About the authors}

Roberto Kolter is the current president of the American Society for Microbiology (ASM). He is a Professor of Microbiology and Molecular Genetics at Harvard Medical School, where he leads the research group in microbial genetics and physiology. His research fields are secondary metabolism of bacteria and their response to lack of nutrients, surface bacterial aggregates (biofilms), and, more recently, chemical communication among species. He received his degree at Carnegie Mellon University in Pittsburgh and his Ph.D. at University of California in San Diego. After postdoctoral studies at Stan- ford, he started teaching at Harvard Medical School. He has received many distinctions, including the Helen Hay Whitney and Charles King Trust grants, a research professorship from the American Cancer Society, and an international professorship from the American Society for Microbiology. He is a Member of the American Academy of Microbiology and was named Senior Scholar by the Ellison Medical Foundation. He was director of the Gordon Conferences on microbia stress response and molecular mechanisms of microbial adhesion. He gives courses on genetics and microbial physiology and is co-director of a new initiative in microbial sciences at Harvard. $\mathrm{He}$ is also a consultant for many pharmaceutical and biotechnology companies, and a member of the consultant committee of Microbia and Arpida.

Deborah Hogan received her A.B. degree in Biology from Harvard University in 1993, and her Ph.D. in Microbiology from the Michigan State University in 1999. After postdoctoral work at Harvard Medical School, Dr. Hogan joined the faculty of the Department of Microbiology and Immunology at Dartmouth Medical School in 2004. In 2005, she was named a Pew Biomedical Scholar for her insightful work on how bacteria interactions affect human health. 